\title{
PENNSYLVANIA'S CLARIFYING AMENDMENT FOR DECLARATORY JUDGMENTS
}

\section{By EDwIN BorCHARD †}

On May 26, I943, the Pennsylvania legislature adopted the following amendment to Section 6 of the Uniform Declaratory Judgments Act, originally enacted in $1923:^{1}$

Sec. 6: Relief by declaratory judgment or decree may be granted in all civil cases where an actual controversy exists between contending parties, or where the court is satisfied that antagonistic claims are present between the parties involved which indicate imminent and inevitable litigation, or where in any such case the court is satisfied that a party asserts a legal relation, status, right, or privilege in which he has a concrete interest and that there is a challenge or denial of such asserted relation, status, right, or privilege by an adversary party who also has or asserts a concrete interest therein, and the court is satisfied also that a declaratory judgment or decree will serve to terminate the uncertainty or controversy giving rise to the proceeding. Where, however, a statute provides a special form of remedy for a specific type of case, that statutory remedy must be followed; but the mere fact that an actual or threatened controversy is susceptible of relief through a general common law remedy, or an equitable remedy, or an extraordinary legal remedy, whether such remedy is recognized or regulated by statute or not, shall not debar a party from the privilege of obtaining a declaratory judgment or decree in any case where the other essentials to such relief are present; but proceeding by declaratory judgment shall not be permitted in any case where a divorce or annulment of marriage is sought. ${ }^{2}$

This amendment, drafted by Chief Justice von Moschzisker after his retirement from the court, has a history going back to I933. It was designed to rescue the Supreme Court of Pennsylvania from a profound error in having emasculated the Declaratory Judgments Act of Pennsylvania by judicial legislation. Briefly, they had professed to discover, in the face of the clear wording of the Declaratory Judgments Act to the contrary, that the Act could not be used where another

广 A. B., Ph. D., Columbia University; LI. B., New York Law School; LL. D. (hon.), Berlin University; Professor of Law, Yale University Law School. Codraftsman of the Uniform Act, the Federal Act, and state acts. Author of numerous articles in leading legal periodicals.

I. Act of June I8, 1923, P. L. 840, Pa. Stat. Annot. (Purdon, I93I) tit. I2, $\S \S 83 I-46$. $\$ 836$.

2. Act of May 26, I943, P. L. 23, Pa. Stat. Annot. (Purdon, Supp. I943) tit. I2, 
remedy was available. The fact is that in most of the judgments they had rendered, another remedy would have been available. But the announcement, reiterated as recently as the two cases of Stoffet \& Tillotson v. Chester Housing Authority, ${ }^{3}$ and Valley R. R. v. Delaware, Lackawanna \& Western $R$. $R$., ${ }^{4}$ both decided on March 22, I943, that a declaratory judgment would not be granted where another remedy was available, was enough to discourage lawyers from seeking to use the declaratory judgment procedure. It became a trap rather than an aid in the administration of justice. The von Moschzisker amendment had been originally passed on April 25 , I935, ${ }^{5}$ but unfortunately, in what was apparently an attempt to gild the lily, some legislator had tacked on an additional amendment reading:

but the case is not ripe for relief by way of such common law remedy, or extraordinary legal remedy, or where the party asserting the claim, relation, status, right or privilege and who might bring action thereon, refrains from pursuing any of the last mentioned remedies. Nothing herein provided is intended to or shall limit or restrict the general powers or jurisdiction conferred by the act hereby amended; but proceeding by declaratory judgment shall not be permitted in any case where a divorce or annulment of marriage is sought. ${ }^{6}$

That additional amendment was so ambiguous and confusing that it enabled the Pennsylvania Supreme Court to adhere to its original mistake, so that the Declaratory Judgments Act was rendered practically useless to the people of Pennsylvania. The re-enactment of the von Moschzisker amendment, without the stultifying appendage, took eight years, and it may now be hoped that the Supreme Court will reverse the mistakes that amendment was designed to cure.

3. $346 \mathrm{~Pa}$. 574, 3I A. (2d) 274 (1943). This was a perfect case for declaratory judgment. A building contractor had sued the Housing Authority for a declaration that a certain delay had breached the contract requiring arbitration under certain clauses thereof, and if so, how much was due the plaintiff. Because it was alleged that the Arbitration Act and action in assumpsit permitted an adjudication of the case, the plaintiff had to submit to this denial of justice. The Court is equally challengeable in saying that "Ordinarily, it [the court] will not act where there is a dispute as to facts, or such controversy may arise." Ladner v. Siegel, 294 Pa. 368, 373, I44 At1. 274, 276 (1928), should have been considered overruled on that point by the United States Supreme Court's opinion in Aetna Life Insurance Co. v. Haworth, 300 U. S. 227, 57 Sup. Ct. 46I, 8r L. Ed. 6I7, rehearing denied, 300 U. S. 687, 57 Sup. Ct. 667, 8I L. Ed. 889 (1937).

4. $346 \mathrm{~Pa}$. 579, 3I A. (2d) 276 (1943). This was also a perfect case for declaratory judgment. One railroad sued the other for a declaration that under a lease between the parties the defendant was obliged to pay certain taxes assessed against plaintiff, one of the commonest forms of declaratory action. See the many declarations cited in Borchard, Declaratory Judgarents (2d ed. 194I) 623, n. 89. On the alleged ground that plaintiff lessor had a remedy at law in assumpsit, the action was dismissed. $\$ 836$.

5. Act of April 25, 1935, P. L. 72, PA. Stat, Annot. (Purdon, Supp. 1943) tit. 12,

6. Ibid. 
The history of the confusion is not difficult to trace. After an excellent beginning with the decision in Kariher's Petition, ${ }^{7}$ a development which lasted for a few years only, the Pennsylvania court slipped into error by suggesting in certain cases, mainly involving wills and probate jurisdiction, that the declaratory action could be employed only when no ordinary form of action was available, because the main purpose of the declaratory procedure, it was said, was to insure a speedy determination of issues "which would otherwise be delayed to the possible injury of those interested if they were compelled to await the ordinary course of judicial proceedings." 8

There is no authority whatever in the history of declaratory procedure for such a supposedly inherent limitation. In a learned article by Professor C. S. Potts entitled "Some Practical Uses of the Declaratory Judgment Law," ${ }^{9}$ the author states:

"A few states have shown a tendency to restrict the usefulness of the Declaratory Judgment Act. In List's Estate, the Supreme Court of Pennsylvania said that relief by declaratory judgment was '. . . provided for the purpose of having issues speedily determined, which otherwise would be.delayed with possible injury to those interested, if . . . compelled to await the ordinary course of judicial proceedings.' While a declaratory judgment was sustained in that case, the court stated that such relief was not available in cases clearly aside from its obvious purpose.' From this slightly conservative suggestion the court has gone on and on until now it has virtually made the declaratory judgment an extraordinary remedy, to be used only if no other remedy is available or is adequate. A similar development has gone on in Maryland. Such treatment of this highly useful and flexible procedure is unfortunate, as it deprives litigants of a very speedy alternative remedy. The Uniform Act is couched in the broadest possible language and, as already noted, it is to be liberally construed and administered.' The question as to whether there is another adequate remedy should never be raised if the facts bring the case under the declaratory statute." 10

Roughly speaking, the declaratory action may be instituted in three types of cases: first, where another action could also have been brought, the action for a declaration being an alternative remedy; the

7. 284 Pa. 455, 47I, I3I Atl. 265, 271 (1925). See Bouldin, J., in Berman v. Wreck-A-Pair Bldg. Co., 234 Ala. 293, I75 So. 269 (1937) ("not dependent on the absence of other remedies").

8. Iist's Estate, 283 Pa. 255, 257, I29 At1. 64, 64-65 (I925) (dictum, for the case was decided). See also Pennsylvania cases cited in BorchaRd, op. cit. supra note 4 , at 3I9, n. II.

9. (I944) 22 TEX. L. REv. 309.

Io. Id. at 32I-322. 
second, involving the construction of written instruments, before or after breach; and third, actions initiated by a challenger or a person in jeopardy, where another action would not have been possible. We are now discussing the first type of case. The justification for an alternative remedy in this class is that the declaratory action affords a less technical, speedier, cheaper and more civilized joinder of issues, in types of cases heretofore associated with hostile combat, the encrusted technicalities of special writs, and irrevocably broken economic relations. The declaratory action proceeds on the assumption that a mild remedy will often satisfy, that responsible defendants do not need more than an authoritative declaration of the law to obey it, and that coercive relief under such circumstances is an expensive and usually unnecessary remedy.

The best evidence that the declaratory action was expected to be employed in such cases is to be found in the words of the statute itself, authorizing the courts to render declaratory judgments "whether or not further relief is or could be claimed." This means that where a coercive remedy, like damages, injunction or specific performance (I) is also claimed; (2) is not claimed and could not be claimed; and (3) could be claimed but is not claimed, this fact shall not bar the use and issuance of a declaratory judgment. The same thought is expressed in Federal Rule 57 by the sentence: "The existence of another adequate remedy does not preclude a judgment for declaratory relief in cases where it is appropriate." In the Act of May 26, I943, this thought is again expressed by the clause:

The mere fact that an actual or threatened controversy is susceptible of relief through a general common law remedy, or an equitable remedy, or an extraordinary legal remedy, whether such remedy is recognized or regulated by statute or not, shall not debar a party from the privilege of obtaining a declaratory judgment or decree in any case where the other essentials to such relief are present.

\section{III}

The Pennsylvania Supreme Court unhappily had construed the statute independently of its words, as if it authorized a petition for an extraordinary legal remedy, to be denied where there is a regular action available, or, like an equitable action, to be dismissed where there is an adequate remedy at law. It should make no difference to a court through which door a petitioner enters the courtroom, provided he stands before the bar. And yet that error, sought to be corrected in most codes of civil procedure, has occasionally persisted. The assumption of Coke, "no writ, no remedy," has been construed under modern 
codes as if the codes provided, "no remedy without a writ;" and that if there was a writ for a particular grievance, that writ alone could be employed. The idea that writs have mainly historical significance and that there might be two or more remedies for a particular grievance has been difficult to convey.

Other courts have in similar fashion on occasion frustrated the use of the declaratory procedure, as was done in the recent Indiana case of Burke v. Gardner. ${ }^{11}$ There the plaintiff landowners sued adjoining landowners for a declaration that a building restriction confining the neighborhood to residential houses was still valid. The defendants had indicated their desire and intent to erect a church on the land, located in a subdivision of the City of Elkhart. On the alleged ground that the plaintiffs could have sought an injunctionnot yet obtained, it is understood-the court denied a declaration, the simplest possible means of disposing of the issue. Even if it were true that the wrong remedy had been asked, modern practice codes usually provide that suits shall not be dismissed on that account, but that if the court had jurisdiction to grant the proper remedy, appropriate amendments in process and pleading shall be ordered. ${ }^{12} \mathrm{~A}$ combination of prayers for relief, declaratory and coercive, and alternative prayers are common practice. Federal Rule 54 (c) has expressly provided that "Every final judgment shall grant the relief to which the party in whose favor it is rendered is entitled, even if the party has not demanded such relief in his pleadings." A prayer for relief is not controlling. ${ }^{13}$ Most of the unfortunate dicta in Pennsylvania decisions were expressed in actions which could have been dismissed on the simple ground that an action involving the identical issue was pending in another court or that another court, such as the Orphans' Court, had exclusive jurisdiction of the case, or that as specifically provided in the von Moschzisker amendment, a special statutory remedy had been provided for that particular type of case.

As already observed, in Pennsylvania and elsewhere a declaratory judgment has actually been granted in the great majority of cases, notwithstanding the fact that the case might have been differently framed for a coercive remedy, or that in fact such a remedy could have

II. 47 N. E. (2d) $x 48$ (Ind. I943).

I2. Cf. Stueck v. G. C. Murphy Co., Io7 Conn. 656, 661, I42 Atl. 301, 303 (I928) ("The rights of the parties are to be determined, as prayed for, upon the facts found. In an action for a declaratory judgment, we are not limited by issues joined, or by the claims of counsel") ; Oddo v. Saibin, 106 N. J. Eq. 453, 460, 15I Atl. 289, 292 (I930). See Lisbon Village Dist. v. Town of Lisbon, 85 N. H. I73, I55 Atl. 252 (I93I), in which the court considered a denied petition for a declaration as equivalent to a petition for tax abatement, which was allowed. (1938).

13. Schaefer v. First National Bank of Findlay, 134 Ohio St. 5II, I8 N.E. (2d) 263 
been sought. ${ }^{14}$ There is no evidence whatever of the fear entertained by some judges that the declaratory action might replace the coercive remedies, since in the vast majority of cases (I should estimate I9 out of 20) a plaintiff desires and requests coercive relief against the defendant. The lack of judicial uniformity in Pennsylvania left the outcome of any particular litigation quite uncertain, for while the objecting party would necessarily undertake to plead that another remedy was available, the final position of the court seemed unpredictable. Lawyers dislike judicial caprice. The doubt as to what position the Pennsylvania courts might take, with risk of complete dismissal, militated against the use of the remedy.

\section{IV}

The Pennsylvania courts stumbled into the error mentioned by misquoting unintentionally what Chief Justice von Moschzisker, speaking with historical authority, had stated in Kariher's Petition. Outlining the functions of the Act, he had remarked in that case, as reiterated in his amendment, that a declaratory judgment would not be entertained "where another statutory remedy has been specifically provided for the character of case in hand," This was in accordance with the standard practice in England and the United States, for it was never intended that a declaratory judgment should be sought where the state had provided a specific form of proceeding for a special type of case, like tax assessment, eminent domain, divorce, annulment of marriage, ${ }^{15}$ or other clearly defined type of issue. But in 1928 , in Leafgreen $v$. La Bar, ${ }^{16}$ the clear statement of Judge von Moschzisker was unintentionally distorted and he was charged with having said that a declaratory judgment would not lie where another "equally serviceable" remedy was available. This of course was something quite different; but by 1933 the phrase had been further transformed into a ground for dismissal where the question "can be litigated in the established course of legal and equitable procedure." 17 This was a

14. In some of the Pennsylvania cases, though the propriety of the action for a declaration was denied, a judgment practically determining the issue was rendered. $C f$. City of Williamsport v. Williamsport Water Co., $300 \mathrm{~Pa}$. 439, I50 Atl. 652 (I930), and List's Estate, 283 Pa. 255, 129 Atl. 64 (1925), cited note 8 supra. In In re Cryan's Estate, 30I Pa. 386, I52 Atl. 675 (1930), the Supreme Court of Pennsylvania cites seven other cases before that court in which wills were construed by declaratory judgment. In practically all of them some other remedy was available.

I5. All that is now left of the stultifying amendment which prevented the von Moschzisker amendment from coming into force between I935 and I943, is the provision that "proceeding by declaratory judgment shall not be permitted in any case where a divorce or annulment of marriage is sought."

16. $293 \mathrm{~Pa}$. 263, I42 Atl. 224 (I928).

17. Nesbitt v. Manufacturers' Casuaity Ins. Co., 3ro Pa. 374, 380, I65 Atl. 403, 405 (1933). In Bell Telephone Co. v. Lewis, 313 Pa. 374, I69 At1. 57I (1934), the phrase used was "adequate remedy." But while correctly quoting Judge von Moschzisker's 
far cry from the rigidly correct position of 1925 . It not only departed from the terms of Section I of the Act and its usual construction, even in Pennsylvania, but if persisted in, was bound to reduce the declaratory judgment action to an extraordinary or exceptional remedy not invokable where another remedy was available..$^{18}$

It is perhaps unnecessary to trace the curious construction given to the appendage tacked on to the von Moschzisker amendment in I935. Suffice it to say that this ambiguous appendage, not intended to stultify the amendment, was construed as if it provided that a declaratory action will not lie unless the case is not ripe for relief by way of a coercive remedy. ${ }^{19}$ Unfortunately, this view, while possibly justified by the confusion of the appended amendment, was in direct contradiction to the whole reason, purpose and sense of the von Moschzisker amendment.

The Pennsylvania legislature has on several occasions indicated its approval of declaratory procedure by enacting practice rules more detailed than those of practically any other state. ${ }^{20}$ The Maryland

language concerning "another statutory remedy," the court erroneously concluded that mandamus is such a special statutory remedy. The case was dismissed on jurisdictional grounds as an action against the State in the person of the Governor. Petitioner claimed the right to construct a telephone line on a State bridge without approval of the Governor and that provision for revocability of the license on six months' notice was unconstitutional. The facts were ideal for a declaration, had the Secretary of State been made the defendant.

I8. It is of course proper not to grant a declaratory judgment where a pending case will decide the issue completely, or where it will not give complete or adequate relief, or where it is premature.

Ig. Allegheny County v. Equitable Gas Co., 32I Pa. I27, I83 Atl. 916 (1936), (1936) Io TEMP. L. Q. 427. This restrictive construction was reiterated in the following Pennsyivania cases: Warren's Petition, 21 D. \& C. 276 (1934); Hume's Estate, 24 D. \& C. 73 (I935), following List's Estate, 283 Pa. 255, I29 Atl. 64 (I925), cited note 8 supra; National Board of Trustees of Theta Chi v. Summer, 28 D. \& C. 307 ( 1936 ) (rights of bondholders under mortgage; held "ripe" for "equitable relief," not mentioned in 1935 amendment); Oberts v. Blickens, 131 Pa. Super. 77, r98 Atl. $48 I$ (I938) (construction of will; right to possession of real estate; ejectment held proper) ; Malick's Petition, I33 Pa. Super. 53, I A. (2d) 550 (r938) (petition to intervene to establish priority of mortgage over tax lien, validity of which was in issue in principal suit); Bergman v. Gross, 329 Pa. 67, I96 Atl. 488 (1938) (plaintiff sued executors to establish right to recover par value of bonds); Stofflet \& Tillotson v. Chester Housing Authority, cited note 3 supra; Valley R. R. v. Delaware, Lackawanna \& Western R. R., cited note 4 supra.

But in the following cases this restrictive construction was not followed: Karns v. East Central Fruit Growers Productive Credit Ass'n., 20 D. \& C. 83 (I934) (that defendants had breached contract in not executing loan; no other speedy remedy available) ; Keister v. Greene, 24 D. \& C. 77 (I935) (right of defendants to foreclose mortgage jointly held in shares by plaintiffs) ; Norristown Borough School Dist. v. Hoffman, 24 D. \& C. 56 (I935) (commission due to defendant tax collector; court thought I935 amendment had "greatly extended" court's jurisdiction); Idell v. Delaware County Poor Dist., 28 D. \& C. 232 (I936) (that contract is valid and in force, plus damages); Indemnity Insurance Co. of North America v. Kirsch, 28 D. \& C. 630 (1936) (coverage of policy); Lansinger v. Lansinger, $26 \mathrm{D}$. \& C. 70I (I936) (that defendant husband's Nevada divorce was invalid); Pennsylvania Milk Products Corp. v. Milk Control Board, 26 D. \& C. 489 (r936) (invalidity of administrative order).

20. See Act of May 22, I935, P. L. 228, Pa. Stat. Annot. (Purdon, Supp. I943) tit. 12, $\$ \S 847-853$, and Act of April 13, I943, P. L. 43, PA. Stat. ANNor. (Purdon, Supp. I943) tit. $12, \$ 848$. 
court has used the declaratory procedure even more harshly than Pennsylvania, for, notwithstanding the presence of the clause "nor shall the existence of another adequate remedy preclude a judgment for declaratory relief in cases where it is appropriate," the Supreme Court of Maryland has construed the Uniform Act of 1939 as if the availability of a common law or equitable remedy made a declaratory judgment not appropriate and unavailable. ${ }^{21}$ Notwithstanding the provision of the Act that it should be liberally construed, some courts have not acted upon that injunction. The fact, however, that all but seven states of this Union, in addition to the federal Government, have now adopted the Act, ${ }^{22}$ and that there have been over 3,000 American cases carrying the statutes into effect, should afford some assurance that the reform is welcomed and has proved its utility.

2I. Caroline Street Permanent Building Ass'n. v. Sohn, 178 Md. 434, 13 A. (2d) 616 (1940). This was a grievous misconstruction. See the criticism of the Maryland Supreme Court in Case, Declaratory Judgment in Maryland (1942) $6 \mathrm{MD}$. L. REV. 22r.

22. All but the following states have adopted the statute: Arkansas, Delaware. Georgia, Illinois, Louisiana, Mississippi and Oklahoma. 